Studia Judaica 23 (2020), nr 1 (45), s. 43-74

doi:10.4467/24500100STJ.20.002.12916

Aleksandra Oniszczuk (iD https://orcid.org/0000-0001-5562-9058

\title{
The Old Privileges and the New Spirit of Law: Jewish Residential Areas in the Duchy of Warsaw
}

\begin{abstract}
Among the most important aspects of government policy aimed at Jews in the nineteenth-century Polish lands was the issue of where Jews could reside. Medieval in its roots, the conviction that some form of separation was needed was vested in contemporary arguments. Pertinent in this context was the stance taken by the authorities of the Duchy of Warsaw. The article discusses the question whether old city privileges imposing restrictions on Jews were in force at that time. The author claims - contrary to previous historiography — that this question cannot be reduced to a simple "yes" or "no" answer. Referring to the concepts of sociology of law, the double dimension of law (law in books and law in action) can be identified. The issue may serve as an interesting example of legal pluralism and the power of law-convictions.

Based on ministerial and local correspondence, the analysis leads to two major conclusions. First, while in theory old city privileges were no longer in forceand this was clearly stated by ministers - the latter decided to refrain from announcing this to the public. Moreover, they agreed to develop an unofficial policy of resolving some cases "as if the old privileges were still binding." Second, the officially introduced concept of district (rewir) was designed to replace the old privileges, as it offered a variety of new justifications. These were linked to the modernization policy, with claims regarding the integration of acculturated individuals, order, sanitation, and safety.
\end{abstract}

Keywords: Duchy of Warsaw, privileges, Old-Polish privileges, privilegia de non tolerandis Judaeis, residential restrictions, history of Polish Jews, sociology of law, legal pluralism.

Słowa kluczowe: Księstwo Warszawskie, przywileje, przywileje staropolskie, privilegia de non tolerandis Judaeis, ograniczenia osiedleńcze, historia Żydów polskich, socjologia prawa, pluralizm prawny. 
Among the most important aspects of government policy aimed at Jews in nineteenth-century Polish lands was the issue of where Jews could reside. Medieval in its roots, the conviction that a type of separation was needed was vested in contemporary arguments. Pertinent in this context was the stance taken by the authorities of the Duchy of Warsaw (1807-1815). Although this state was short-lived, it adopted a series of legal acts that for years afterwards functioned as the point of departure or reference for Jewish policies pursued by the authorities of its successor, the Kingdom of Poland, from 1815. Among these legal acts and resolutions was an 1809 regulation reducing Jewish presence in over thirty central Warsaw streets, deemed the best addresses in town.This legislation was one of the most frequently quoted of the Duchy's legal acts in the Kingdom. ${ }^{1}$

Reference to continuity explains most cases when historiography decides to revisit the Jewish policies of the Duchy of Warsaw. These references are often based, however, upon arguments found in later sources, under the assumption that the purposes and views of governmental decision-makers in both states were identical. However, research focused specifically on the Duchy has shown that even though many members of authority bodies continued to work in public administration, one cannot equate the ways of understanding and the validity of law in the two bodies politic: their Jewish policies were not identical.

This article explores an issue considered by historiography to be a manifestation of continued Jewish policy: namely, the binding force in the Duchy of Warsaw of Old Polish privileges restricting the spaces available to Jews for settling within urban areas-in particular, the de non tolerandis Judaeis privileges. ${ }^{2}$ Following the now-classical studies by Artur Eisenbach, scholars repeatedly stated that the "privileges not to tolerate Jews," abolished in 1802 under the Prussian Partition, were reinstated in the Duchy and subsequently maintained in the Kingdom of Poland. ${ }^{3}$ I argue that

${ }^{1}$ For the contents of the decree, see Ustawodawstwo Księstwa Warszawskiego. Starodawne prawa polskiego pomniki [henceforth: UKW], Series II, Section IV, eds. Wojciech M. Bartel, Jan Kosim, Władysław Rostocki (Warsaw, 1964-1969), 2:26-29, 88-90.

${ }^{2}$ I would like to thank Simon Behnisch, Piotr M. Pilarczyk, and Michael K. Schultz for their valuable comments on previous versions of the article.

${ }^{3}$ Artur Eisenbach, "Mobilność terytorialna ludności żydowskiej w Królestwie Polskim," in Witold Kula (ed.), Społeczeństwo Królestwa Polskiego. Studia o uwarstwieniu i ruchliwości społecznej (Warsaw, 1966), 2:185; id., Kwestia równouprawnienia Żydów w Królestwie Polskim (Warsaw, 1972), 100; id., Emancypacja Żydów na ziemiach polskich 1785-1870 na tle europejskim (Warsaw, 1988), 154; Janusz Szczepański, Dzieje społeczności żydowskiej powiatów Pultusk i Maków Mazowiecki (Warsaw, 1993), 27; id., Spoteczność żydowska Ma- 
this complex subject can be analyzed from different perspectives. Case studies herein will develop the general thesis-formulated chiefly by legal historians - that new regulations in the Duchy of Warsaw coexisted with earlier legal practices, and that there existed a clear divergence between law and reality. ${ }^{4}$

After giving a short summary of the role of privileges in the Polish legal tradition, I examine the ministerial interpretation of these regulations and assumptions regarding Jewish residential policy, both at regional and local levels. I highlight an issue of keen interest to the sociology of law: the tension between legal regulations (the "law in books") and legal practice (the "law in action"). The analysis rests on the premise that further research - beyond investigation of the legislation in force-is both legitimate and justifiable, as law is "a social product-a complex of activities of real people with socially shared and produced, but individually carried out, legal and nonlegal ideas, beliefs, motivations, and purposes. Law is inseparable from and embedded in—an integrated aspect of—-social life. ${ }^{5}$

\section{The privileges tradition}

Town privileges restricting the space available to Jews were issued from the Middle Ages on, initially compiled solely by monarchs and, with time, created also by owners of private towns, whether alongside

zowsza w XIX-XX wieku (Pułtusk, 2005), 44-45; François Guesnet, Polnische Juden im 19. Jahrhundert: Lebensbedingungen, Rechtsnormen und Organisation im Wandel (Köln-Weimar-Wien, 1998), 36; Henryk Bartoszewicz, "Projekty rewirów dla ludności żydowskiej w miastach mazowieckich 1807-1830," Rocznik Mazowiecki 18 (2006), 106; Curtis Murphy, From Citizens to Subjects: City, State, and the Enlightenment in Poland, Ukraine and Belarus (Pittsburgh, 2018), 159-160. Let us note that while Eleonora Bergman mentions the attempts "at formally restoring and enforcing by the Duchy of Warsaw government" of the de non tolerandis Judaeis privileges, she aptly points to the inefficient efforts to remove Jews from localities where they had settled under Prussian rule; see Eleonora Bergman, "Ludność żydowska w miasteczkach Mazowsza w XIX i XX w.," in Andrzej Stawarz (ed.), Mazowieckie miasteczka na przestrzeni wieków. Wybrane zagadnienia rozwoju gospodarczego, społecznego i kulturowego (Warsaw, 1999), 82.

${ }^{4}$ Władysław Sobociński, Historia ustroju i prawa Księstwa Warszawskiego (Torun, 1964), 7, 295-296; Marian Kallas, Organy administracji terytorialnej w Księstwie Warszawskim (Toruń, 1975), I-II; Józef Mazurkiewicz, "Znaczenie akt notarialnych dla badań nad własnością w Księstwie Warszawskim i Królestwie Polskim,” Annales UMCS, Sec. F, 20 (1965), 116-117. Note also Jarosław Czubaty's postulate to examine the "structures of power at the lowest levels" in Jarosław Czubaty, The Duchy of Warsaw, 1807-1815: A Napoleonic Outpost in Central Europe, trans. Ursula Phillips (London, 2016), 110-111.

${ }^{5}$ Brian Tamanaha, "A Holistic Vision of the Socio-Legal Terrain," Law and Contemporary Problems 71 (2008), 2:89-90 (a reference to Marc Galanter's view of law). 
the development of new urban centers or as amendments to existing regulations. The restrictions consisted in specifying the following: (i) the maximum number of Jewish houses permitted within an urban center; and/or (ii) the streets or parts of town wherein Jews were allowed to dwell (not, however, representing ghetto areas); or (iii) a complete ban on settlement (privilegium de non tolerandis Judaeis). The rationale behind such restrictions reflected religious and cultural biases (revealing anti-Jewish attitudes, a perception of otherness) and stemmed also from economic concerns (exhibited by a desire to restrict professional competition). While individual Jews made efforts to circumvent the bans imposed in the urban privileges, the separation brought some limited benefits to the Jewish community as a whole, ensuring a higher sense of security and facilitating community life. ${ }^{6}$

${ }^{6}$ The literature dealing with this subject matter is extensive; see, for example, Majer Bałaban, Dzielnica żydowska - jej dzieje i zabytki (Lwów, 1909), 10-11, 15, 30-33; Zofia Baranowska, Jerzy Baranowski, "Dzielnica żydowska i synagoga w Zamościu,” Biuletyn Żydowskiego Instytutu Historycznego 63 (1967), 40; Jacob Goldberg, "De non tolerandis Iudaeis: On the Introduction of the Anti-Jewish Laws into Polish Towns and the Struggle against Them," in Shmuel Yeivin (ed.), Studies in Jewish History: Presented to Professor Raphael Mahler on His Seventy-Fifth Birthday (Merhavia, 1974), 39-52; Maria Piechotka, Kazimierz Piechotka, "Jewish Districts in the Spatial Structure of Polish Towns," Polin 5 (1990), 24-39; eid., Oppidum Judaeorum. Żydzi w przestrzeni miejskiej dawnej Rzeczypospolitej (Warsaw, 2004), 22-23; Paweł Fijałkowski, "Żydzi w miastach Mazowsza XIII-XVIII w.," in Stawarz (ed.), Mazowieckie miasteczka, 60-74; id., Warszawska społeczność żydowska w okresie stanistawowskim 1764-1795. Rozwój w dobie wielkich zmian (Warsaw, 2016), 50-69, 73, 80-84, 89-91, 127-131, and passim; Stefan Gąsiorowski, "Żydzi w Kiejdanach w XVII i XVIII w. Rekonesans badawczy," in Marcin Wodziński, Anna Michałowska-Mycielska (eds.), Matżenstwo z rozsądku? Żydzi w społeczeństwie dawnej Rzeczypospolitej (Wrocław, 2007), 78-82; Anna Michałowska-Mycielska, "Żydzi w strukturze politycznej i administracyjnej Rzeczypospolitej (XVI-XVIII w.)," Przeglad Humanistyczny 58 (2014), 3:119-120; ead., The Jewish Community: Authority and Social Control in Poznan and Swarzędz 1650-1793 (Warsaw, 2015), 13-21; Glenn Dynner, "Jewish Quarters: The Economics of Segregation in the Kingdom of Poland," in Rebecca Kobrin, Adam Teller (eds.), Purchasing Power: The Economics of Modern Jewish History (Philadelphia, 2015), 91-93; Hanna Węgrzynek, "Illegal Immigrants: The Jews of Warsaw, 1527-1792," in Glenn Dynner, François Guesnet (eds.), Warsaw. The Jewish Metropolis: Essays in Honor of the 75th Birthday of Professor Antony Polonsky (Leiden-Boston, 2015), 24, 29, 31-38, 42; Adam Kaźmierczyk, “Żydzi w miastach prywatnych. Wybrane aspekty," Roczniki Dziejów Społecznych i Gospodarczych 77 (2016), 363-365. For the most complete argument on the irrelevance of the term "ghetto" to Jewish districts in Poland-Lithuania, see Jürgen Heyde, "Ghetto' and the Construction of Jewish History: The Case of the Polish-Lithuanian Commonwealth. Considerations about a Research Project," Kwartalnik Historii Żydów (2004), 4: 511-518; id., "The 'Ghetto' as a Spatial and Historical Construction - Discourses of Emancipation in France, Germany and Poland," Jahrbuch des Simon-Dubnow-Instituts 4 (2005), 431-443. On the deeply rooted incentives behind separating the Jewish spaces and the concept of "subtenancy" with respect to Jews 
From a broader perspective, both individual and group privileges were permanent fixtures of the legal framework of the Polish-Lithuanian Commonwealth. The country's legal culture was based on a mosaic of regulations, including laws bestowed separately upon each social estate, consisting of estate-specific rights and obligations. The privileges obtained by the nobility over several hundred years formed the basis for the crucial role of this particular estate. The functioning of Jewish communities since the Middle Ages was based on acceptance by the external authorities, also expressed in the form of privileges. ${ }^{7}$ The lives of entire towns or cities were regulated quite similarly. The town foundation privileges were the basis for imposing local levies or organizing fairs-events of key importance to the trade. The emergence of jurydykas (autonomous settlements) was also a result of the granting of individual privileges to owners of real estate within royal towns. And to mention a final factor-disputes in towns between Christians and Jews, mainly regarding problems of jurisdiction and distribution of municipal burdens and commitments, occurred around the question of privileges. ${ }^{8}$ The common perception was that the privileges were natural and served as the basic instrument for regulating social and economic relations in Poland-Lithuania. It was only in the Commonwealth's last years that wider concepts were formulated with the intention to restrict the effects of privileges and replace them by some uniform legislation; these were manifested, among other ways, by putting into effect the alcohol monopoly law (propination law) in $1776,{ }^{9}$ the adoption of the act on towns and, lastly, the Constitution of the Third of May 1791.

These actions were aligned with postulates, put forth in the debate in many European states at the time, to abolish some of the territorial and profession-related particularisms - and, in more general terms, to restrict

residing in the Polish lands: Konrad Matyjaszek, Produkcja przestrzeni żydowskiej $w$ dawnej i wspótczesnej Polsce (Kraków, 2019).

7 Jewish Privileges in the Polish Commonwealth, ed. Jacob Goldberg (Jerusalem, 19852001), vols. 1-3.

${ }^{8}$ For more on the importance of privileges in Poland-Lithuania, see Murphy, From Citizens to Subjects, 8-10, 16, 19, 25-85.

9 The urban alcohol production (propinacja) law introduced a government-supervised alcohol monopoly. It was designed as a tool to bring order to towns and to improve their financial condition. It aimed to limit the old burghers' privilege- an exclusive right to produce alcohol within the town limits. For now on, alcohol production in every royal town (excluding the largest ones) was to be in hands of an individual winning an official auction. An excellent analysis of the issue is provided by Curtis Murphy, see ibid., 53-82. 
the power of municipal governments and to liquidate guilds and confraternities, against an increased scope of the central authorities' power. ${ }^{10}$ The Revolution-swept France excelled at handling such matters, as it strove for legal unification of its entire territory by, for example, abolishing guilds and confraternities (through the Le Chapelier Law of 1791). This trend was reinforced soon afterward by Napoleonic legislation (the Constitution, the Civil Code, the Code of Civil Procedure, and the Commercial Code). On a much larger scale than in Poland-Lithuania, the unifying and centralizing policy was observable in neighboring Prussia, where the enlightened absolutism model was being implemented. Also in the newly seized Polish territory, Prussia endeavored to replace the diffusing Old Polish legal regulations by attempting to introduce some codified rules, designed for the entire state (Allgemeines Landrecht, 1794) ${ }^{11}$ or binding for narrower areas but rendering the status of the group concerned standardized (the Generaljudenreglement, 1797). ${ }^{12}$

This unifying exercise pursued by the Prussian authorities was, however, not absolute; particularly in the areas of the Third Partition a limited, auxiliary application of certain Old Polish regulations or customs was admitted so as to prevent disturbances, e.g. in the functioning of the judiciary. The institution of privileges was not rejected as such; instead, it was confirmed that various categories of residents or urban centers were continually entitled to such instruments. Nonetheless, the privileges once granted to Jews under the Commonwealth laws, such as those instituting

${ }^{10}$ Ibid., 4-12, 17-21, 53-120; Jerzy Michalski, "Zagadnienie polityki antycechowej w czasach Stanisława Augusta," Przegląd Historyczny 45 (1954), 4:635-651; Józef Mazurkiewicz, Jurydyki lubelskie (Wrocław, 1956), 107-116.

${ }_{11}$ The literature rightly calls into question the alleged innovative quality of the Landrecht, pointing in particular to its non-transparent hierarchical structure and solidification of the former estate relationships and legal habits. Despite these shortcomings, the regulation in question expressed the legislators' strife to (re)organize the legal reality in an orderly manner. The initial plan was also to systematize the legacy customary law existing theretofore in the Second and Third Partition territories. For more on this topic, see Zbigniew Radwański, Jan Wąsicki, "Wprowadzenie Pruskiego Prawa Krajowego na Ziemiach Polskich," Czasopismo Prawno-Historyczne 6 (1954), 1:184-200, 219-220, and the study of Reinhart Koselleck, Preussen zwischen Reform und Revolution: Allgemeines Landrecht, Verwaltung und soziale Bewegung von 1791 bis 1848 (Stuttgart, 1967).

${ }_{12}$ For this particular legal act, see Jürgen Heyde, "Zwischen Polen und Preußen - Die jüdische Bevölkerung in der Zeit der Teilungen Polens," in Helga Schnabel-Schüle, Andreas Gestrich (eds.), Fremde Herrscher - fremdes Volk: Inklusions- und Exklusionsfiguren bei Herrschaftswechseln in Europa (Frankfurt am Main, 2006), 317-319, 324-326; Albert A. Bruer, Geschichte der Juden in Preußen (1750-1820) (Frankfurt-New York, 1991), 157158; Andrzej Wojtkowski, Polityka rządu pruskiego wobec Żydów polskich od roku 1793 do 1806 (Poznań, 1923), 21-32, 42. 
settlement or professional freedoms, were meant to be the exception: in compliance with the general policy, they ceased being valid ever since. In turn, the privileges pertaining to Jews but vested in Christians were to remain valid. ${ }^{13}$ The Generaljudenreglement retained, for instance, privileges of certain towns limiting the residence of Jews strictly to an indicated area (German, Revier; hence the Polish rewir, rendered below as "district"). Deviations from this principle were admitted: pragmatic considerations and a wish to invigorate the construction business led to permissions being granted to construct buildings outside the designated area within such a town, under the condition that no Christian would be interested while the opportunity-seeking Jew would receive the relevant permit from the authorities. It was moreover admitted that individual towns, pursuant to the decision of their Christian residents, quit their privileges restricting Jewish residence. Hence, this regulation implied that privileges unfavorable to Jews were maintained whilst the way was paved open for their abolishment.

The Generaljudenreglement contained no mention of de non tolerandis Judaeis clauses, accepting them tacitly. Moreover, in 1798 the Berlin-based Generaldirektorium, in its function as a sort of Prussian central government, formulated a clear corroboration of their binding force. ${ }^{14}$ These authorities, however, changed their outlook, and in 1802 announced the dismissal of the privileges preventing towns and guilds of South and New East Prussia from accepting Jews:

Ever since, no consideration ought to be given to the privileges of the former government of Poland, bestowing certain towns and guilds in South and New East Prussia the right not to accept Jews, or to remove them from participation in the craftsmanship. Such privileges, by means of this present declaration, are denied the force of law, and we repeal them, prohibiting our dicasteries and courts from

${ }^{13}$ Manfred Jehle, “'Relocations' in South Prussia and New East Prussia: Prussia's Demographic Policy towards the Jews in Occupied Poland 1772-1806," The Leo Baeck Institute Year Book 52 (2007), 1:24, 30-31, 43-46; Jan Wąsicki, Ziemie polskie pod zaborem pruskim. Prusy Nowowschodnie (Neuostpreussen) 1795-1806 (Poznań, 1963), 76-82, 91-97, 148-157. Cf. id., Ziemie polskie pod zaborem pruskim. Prusy Południowe 1793-1806. Studium historycznoprawne (Wrocław, 1957), 66, 98, 101, 107, 177-178, 196-197, 274-285, 308-309 (Wąsicki noted a shift in the Prussian policy after the 1794 Kościuszko Uprising, resulting in an increased acceptance of Old Polish regulations or customs).

14 Jehle, "Relocations'," 45; Cornelia Aust, "Merchants, Army Suppliers, Bankers: Transnational Connections and the Rise of Warsaw's Jewish Mercantile Elite (1770-1820)," in Dynner, Guesnet (eds.), Warsaw. The Jewish Metropolis, 66. 
accepting any complaints raised thereupon, so that they dare not allocate any such rights, whatsoever. ${ }^{15}$

The abolition of the non-toleration privileges was driven primarily by the intention to extend direct control over the Jewish population and to render the policies in respect to this group dependent upon municipalities. The regulation should moreover be interpreted in the context of Prussia's Jewish demographic policy, which primarily strove to have this group resettled from rural into urban areas. Maintenance of de non tolerandis Judaeis privileges would not have suited the central authorities, particularly in towns that, according to a general assumption, would be made the seats of fiscal authorities and become trade and commerce hubs; such centers were to become settlement areas for Jews. ${ }^{16}$

\section{Regulations and assumptions behind policies: The ministers' interpretation}

The Duchy of Warsaw was created in July 1807 out of a portion of the Prussian Partition territory and was enlarged in 1809 with the annexation of part of the Austrian Partition lands. The Duchy resembled Napoleonic France in terms of centralization and unification policies, as well as in terms of assumptions and official declarations. With its strict subordination to France and its supreme authority passed to Napoleon's loyal ally, King of Saxony, Frederick Augustus I-who also served as Duke of Warsaw- the state was also obligated to follow the French emperor's policies in the field of legislation. Representatives of France, Marshal Louis Nicolas Davout and the so-called residents, were among those who inspected the ways and methods in which Napoleon's will was fulfilled. Yet it was the king, known for his attachment to legalism and rule of law, who had a crucial role in this respect: his opting for Bonaparte and the authority over the Duchy bestowed by the emperor sufficed for Frederick Augustus to feel obligated to be attentive and to see that the Napoleon's will was most strictly fulfilled. ${ }^{17}$ Making use, therefore, of the right of final vote granted to him in respect to legislation (as the official "issuer" of decrees),

15 Quoted in Eisenbach, "Mobilność," 184.

${ }^{16}$ This interpretation has been proposed by Jehle, "Relocations'," 26, 39, 45. See also Bruer, Geschichte, 160.

17 Juliusz Willaume, Fryderyk August jako ksiązę warszawski (1807-1815) (Poznań, 1939), 16-17, 22-25, 89, 92-94; Arkadiusz Bereza, "Pozycja monarchy w Księstwie War- 
Frederick Augustus influenced the discussions within the Council of State and the Council of Ministers on draft legal acts. Based on an extensive analysis of historical records created at the central level, it can be concluded that the king's impact was twofold. On the one hand, he acted as an initiator-personally voicing his doubts with respect to the legality of certain acts and proposed amendments or corrections to the drafts of decrees, in line with the idea of Napoleonic law. ${ }^{18}$ On the other hand, it may be supposed that he might have exerted an inhibiting influence, as the ministers tended to restrain themselves, at least in writing, when it came to proposing solutions deemed too close to the Old Polish tradition-which Napoleon had rejected—or even to the 1791 Constitution. A sort of "political correctness," or "self-censorship," was thus maintained by the king himself and by the ministers reporting to him and forming the core of the Duchy's central authority. It should be noted, however, that these issues concerned official politics and the sphere of declarations; aspects of actual practice will be dealt with below.

The aforementioned legal and constitutional links with France likewise influenced the Duchy's policies toward Jews. The inspiration may be observed both in the very declaration of equality and in the form of restrictions designed to "civilize" the Jews. Article 4 of the Constitution heralded an unprecedented and radical (for those days) change in social relations through the abolishment of bondage and the implementation of legal equality regardless of religious denomination. The effectiveness of this provision with respect to Jews was restricted by means of Frederick Augustus's 1808 decree-modeled upon the French décret

szawskim," Studia Iuridica Lublinensia 18 (2012), 11. For the most comprehensive presentation of the history of this state, see Czubaty, The Duchy of Warsaw.

${ }^{18}$ For instance, Frederick Augustus to the Council of Ministers, 14 Aug. 1811, in Archiwum Główne Akt Dawnych [henceforth: AGAD], collection: Rada Ministrów Księstwa Warszawskiego [henceforth: RM KW], call no. II 165, p. 70; Frederick Augustus to the Council of Ministers, 27 Mar. 1811, in AGAD, RM KW, call no. II 166, pp. 45-46; Frederick Augustus to the Council of Ministers, 21 Sept. 1812, AGAD, RM KW, call no. II 168, p. 34; Hipolit Grynwaser, Kodeks Napoleona w Polsce. Demokracja szlachecka 1795-1831 (Wrocław, 1951), 51; and Willaume, Fryderyk August, 122; John Stanley, "The Politics of the Jewish Question in the Duchy of Warsaw, 1807-1813," Jewish Social Studies 44 (1982), 1:50-51. Glenn Dynner (Dynner, "Jewish Quarters," 93-95), referring to the research by Bina Garncarska-Kadary, recalled a severe decree issued by Frederick Augustus in 1813 confining the majority of Warsaw Jews to the northwestern section of the city. The king's personal role was implied. However, primary sources do not support this opinion, and it seems that such a decree was never adopted. It is noteworthy that, in January 1813, Russian troops marched into the Duchy's territory and Frederick Augustus lost his previous position; these facts further mitigate against the likelihood of the king's involvement. 
infâme-suspending their civic and political rights for ten years, under the pretext of "insufficient standards of civilization." The decree expressed the hope that the distinct external features characterizing Jews would disappear within the timeframe concerned. An option for said rights to be bestowed individually — on a discretionary basis — was provided for (but no secondary legislation implementing it was ever adopted)..$^{19}$ The policy pursued by the Duchy authorities with respect to Jews was thoroughly inconsistent: equality postulates and first attempts at their implementation by the administration existed alongside traditional ideas and concepts, social habits, and practices. Ambivalent views on the Jewish question voiced at the central level were implied, on the one hand, by genuine fears of a radical change in social relations if equal rights for Christians and Jews were introduced-and, on the other hand, by the strife to acculturate the Jews, propelled by the Enlightenment optimism about the possibility to shape (and "civilize") people by means of a rationally constructed law. Another factor that fed the inconsistencies in the Duchy's Jewish policy was its non-priority status: against the multiplicity of affairs considered more important, comprehensive standardization of the status of this particular group was pigeonholed. Instead, individual solutions were adopted ad $h o c$, resulting in incoherent action. Inconsistency in the policies involving Jews was reflected in divergent decisions made on the central and local levels. While the authorities at the lowest level neglected the altered legal environment, the ministers and their associate counsels or referendaries far better understood the character of the new institutional framework. ${ }^{20}$

As regards the binding force of the de non tolerandis Judaeis privileges in the Duchy of Warsaw, it is worth recalling those sources identified by Eisenbach as indicating that such clauses must have been reinstated. Namely, he points to the contents of three resolutions of the Governing Commission, an interim central-level authority, issued in January and June 1807-that is, prior to the formal establishment of the Duchy and the constitutional determination of its political system. The first of these resolutions actually did expressly bring back all the privileges of

${ }_{19}$ UKW, 1:142-143, 148. More on this topic: Eisenbach, Emancypacja Żydów, 150-163; Stanley, "The Politics," 49-51.

${ }^{20}$ For a broader discussion on the subject, see Aleksandra Oniszczuk, "The Jews in the Duchy of Warsaw: The Question of Equal Rights in Administrative Theory and Practice," Polin 27 (2015), 63-87 (including a historiographical overview); ead., Wtadze Księstwa Warszawskiego wobec Żydów. Debata, prawo, praktyka (Wrocław, 2021) (forthcoming). 
the towns; the other two referred to the subject indirectly. ${ }^{21}$ Eisenbach does not mention one other resolution-dated 22 July 1807, which was adopted in Dresden immediately after members of the highest authorities acquainted themselves with the Constitution. At that point, the Governing Commission, in its intent to calm the population, stated as follows: "It shall be our will that all the rights and privileges, those of burghers and those of peasants, bestowed whether under the Polish or the Prussian government, be piously preserved." 22 However, a number of premises suggest that with the official emergence of the Duchy, with its legal order largely built from scratch, the highest authorities did not recognize these privileges as binding.

This is testified by numerous statements or remarks made by ministers who refused to recognize the town privileges limiting the urban spaces accessible to Jews. Such privileges were referred to in broad terms, without specific mention of the non-toleration ones. Pointing to excessive tax burdens borne by Jews, Feliks Łubieński, the Minister of Justice, stated in an aside comment that:

In contemporary law the old privileges lose their binding force, all the more so when they oppose the essential principles of this law. The Constitution admits all denominations and does not exclude any person from their civic rights. It seems, therefore, that any provisions laying further burdens upon Jews not only seem unjust in themselves but are also unlawful. ${ }^{23}$

In the course of another central-level debate-in this case concerning where Jews could reside in Kraków—Jan Paweł Łuszczewski, the interior

${ }^{21}$ The resolution on political system, dated 26 January 1807, in its part on towns stated as follows: "The national towns [i.e., former royal towns, A.O.'s note] shall have their privileges retained" ( $\$ 40)$; and "Hereditary towns [i.e., private towns] shall, equally thereto, have their privileges retained" (\$ 43); quoted in Materiaty do dziejów Komisji Rzadzacej z 1807 r. Dziennik czynności Komisji Rządzacej, ed. Michał Rostworowski (Kraków, 1918), 1:502-503. The other resolution quoted by Eisenbach (of 6 June 1807), on the court proceedings, referred to the rights allocated to each of the estates; the third, dated 18 June 1807 and also concerning the judiciary, merely mentioned the multiple laws of individual towns ("The domestic towns, being of so diverse a sort, may not, each thereof, have their specific provisions, but instead, their internal organization shall be subject to courts of appeals delegated to this end. The said organization is to comply with the one of higher-tier courts of law, whilst the order of the former government is hereby recommended, albeit somewhat restricted": ibid., 675, 702).

22 Ibid., 304.

${ }^{23}$ The Minister of Justice to the Minister of Internal Affairs, 19 Feb. 1808, in AGAD, collection: Komisja Rządowa Spraw Wewnętrznych [henceforth: KRSW], call no. 6627, pp. 13-14. 
minister directly responsible for the Duchy's Jewish policy, expressed his view that the old agreements between the local kahal and Kraków's municipality, like the privileges and constitutions of Poland-Lithuania limiting dwelling space to the "Jewish Kazimierz" area, were rendered invalid "as they were founded upon the difference between confessions now abolished by the Constitution." To his mind, these contracts, privileges, and constitutions may, or even should, be replaced by "police regulations," due to the excessive density of Jewish residents in Kazimierz. The point was to prevent detrimental effects of "the disorderliness of the Jews upon their health and of the other residents." The Council of Ministers agreed with this position and similarly stated that the former agreements, privileges, and constitutions were rendered null and void, and they should be replaced by police regulations. ${ }^{24}$

The issue of the validity of town privileges reappeared with the interesting case of Wolf Drezner of Lublin, who sought consent to reside in the local Catholic Town. The municipal council and some Christian citizens of Lublin were opposed to this, putting forward the question of former privileges among their main arguments. The possible consent would, to their minds, have stood in opposition to "all the privileges bestowed upon this city." Their justification was extensive: they referred to the city's founding act issued by the King Ladislaus the Short in the fourteenth century and the later privileges. They attached to their petition an extensive agreement between the municipality and the local Jews, dating to the last years of the Commonwealth and limiting the area of Jewish residence, and a decision from the period of Austrian rule. They requested that "the High Legislative Authority deign graciously to preserve the privileges serving this city, ensuring enlargement of commerce, as they remain unaffected in their power." 25

However, members of the Council of Ministers did not share the view of the municipality and some of the local burghers. The Minister of Police was confident that

the previous town privileges, in so far as they were not confirmed by His Royal Highness, may not be deemed binding. This is evidenced supremely by the decree of 1809 , wherein H.R.H. orders the Old Testament believers to leave the main

${ }^{24}$ The Minister of Internal Affairs to the Council of Ministers, 4 Feb. 1811, in AGAD, RM KW, call no. II 166, p. 29; Resolution of the Council of Ministers, 1 Mar. 1811, in ibid., pp. 39-41.

25 The Lublin Municipality, together with the burghers, to the Council of State, 24 May 1811, in ibid., pp. 47-53; Agreement of 27 Apr. 1780, in ibid., pp. 59-70; Decision of 13 Jan. 1804, in ibid., pp. 71-72. 
streets of the capital city of Warsaw, not mentioning the privileges of this city. $\mathrm{He}$ merely deigned to say that this is because of the excessive concentration of Old Testament people, who expose the residents of the capital to multiple perils. ${ }^{26}$

According to him, the old privileges had lost their validity, as proved by the decree of 16 March 1809 regarding Warsaw, which neglected the de non tolerandis Judaeis privilege vested in the city. Also, the Minister of Justice opposed acknowledging the privileges of Lublin:

It may not be denied that Wolf Drezner, the Old Testament believer, may have his apartment in the city of Lublin, in spite of the fact that the city of Lublin opposes it. [The reason is that] the privileges that the city of Lublin has submitted in its defence, not approved by the present government, do oppose the Constitution of the Duchy of Warsaw whereby everybody is equal in the face of the law; and, therefore, there is no exception that would be accepted with regard to religious denomination, and by no means may it be worthy of any notice, whatsoever. ${ }^{27}$

A similar view was expressed by the Minister of Internal Affairs. He stated that the former privileges of towns imposing certain bans or prohibitions with regard to Jews had expired, and therefore the local authorities could not invoke them:

Whatever the particular privileges of the city of Lublin might be, to the end that Jews be removed from enjoying certain rights therewithin, they may not be quoted presently. Whereas, namely, the Constitution of the Duchy of Warsaw admits no difference amongst the residents as to religion; therefore, all the foregone regulations and privileges grounded in this principle shall be vacated of their own accord. Nevertheless, this would not apply to the regulations that the former government has made, or the present government may make, this owing to the difference in the customs and in the standards of civilization between the diverse classes of residents..$^{28}$

The minister elaborated on his argument in a rather astonishing manner:

However, despite the invalidity of such particular privileges, it is the opinion of the Minister of Internal Affairs that, in general, it is not appropriate that they be clearly abolished so that Jews be permitted, under no conditions at all, to reside in the principal places of towns where they had not hitherto been allowed to have

26 The Minister of Police to the Council of Ministers, 7 June 1811, in ibid., pp. 73-74.

27 The Minister of Justice to the Council of Ministers, 12 July 1811, in ibid., pp. 85-86. The notice is signed by Łubieński's deputy, but it is marked as the minister's opinion.

${ }^{28}$ The Minister of Internal Affairs to the Council of Ministers, 21 June 1811, in ibid., pp. 76-77. 
their dwellings. This would have stood in plain contradiction to the government's actions regarding the other towns where those [Jews] dwelling had already been instructed to move away from the superior streets. Examples of this are in Warsaw and Wschowa. Under certain conditions, though, Jews could be permitted to reside in those streets where they had hitherto been supposed not to reside. A list of these conditions, serving as a model, is included in the decree ... regarding the removal of Jews from the superior streets of the city of Warsaw. Only the quantity of wealth might be diminished relative to the size of the towns. ${ }^{29}$

The minister's arguments clearly point to the problem of adapting theory-the official legal situation - to the prevalent reality and social relations of the time. Although the minister confirmed that the town privileges related to Jews were no longer in force, he postulated that the authorities withhold from disseminating information on their abolishment. He was of the opinion that Jews should not be granted permission to settle and reside unconditionally in those areas where they had hitherto been banned. He aptly pointed to the fact that this would have been contradictory to the residentiary limitations already imposed in two towns within the Duchy-Warsaw and Wschowa. ${ }^{30}$

What Łuszczewski opted for was issuing consents for habitation in formerly restricted areas within towns, which would meet individual Jewish demands. The Jews were expected to satisfy the conditions provided for in the 1809 decree. That would not infringe the Constitution, the minister believed: "These restrictions are not contrary to the Constitution, and thus, for police-related reasons and due to the need to destroy the external difference . . . between Jews and other inhabitants, the government has the right to undertake them." 31

Referring to police requirements was typical of the time, when the idea of bringing order and controlling the population became crucial for public policy. What was not typical, however, was Łuszczewski's further legal reasoning. Having presented his position on the Drezner case, the minister resumed his general remarks that burghers of Lublin must not

${ }^{29}$ Ibid.

${ }^{30}$ The minister thus makes reference to the aforementioned ban on residence of Jews in the exquisite streets of Warsaw, issued 16 March 1809, and to the decree of 5 July 1810 regarding the town of Wschowa (German: Fraustadt) whereby the local Jews were instructed to leave the Old Town area and move to the New Town (Decree of Frederick Augustus, in AGAD, RM KW, call no. II 165, pp. 33-34; and the Minister of Internal Affairs to the Council of Ministers, 26 July 1811, in ibid., p. 46).

${ }^{31}$ The Minister of Internal Affairs to the Council of Ministers, 21 June 1811, in AGAD, RM KW, call no. II 166, p. 77. 
"hide behind their privileges, for the latter have expired through the annulment of their rule." Subsequently, he presented a surprising approach: "the government, however, shall take them into consideration [emphasis added, A.O.], in as much as they be in concord with its principles and good orderliness of things." 32 This was a clear proposal to pursue a dual policy, both official and unofficial. It seems that the former was meant to educate local communities and municipalities, in particular, to initiate them into the new legal culture. The latter was conditioned by more pragmatic considerations: the point was namely to prevent a massive influx of cases concerned with relocating Jews into town areas that they had previously not populated. An unverbalized or unconscious reluctance to allow an increased presence of Jews in places considered representative could have been equally significant.

Evidence for conducting such official policy is behind an intriguing case from Piotrków. Łuszczewski received a petition from this town and was asked to order forty Jewish families to move from their new dwellings and resettle within the former Jewish residential area (the starosta land). ${ }^{33}$ Contrary to what one might expect, the authors of the petition were not Christian burghers but representatives of the local kehillah. To ensure that the petition would be heard, its authors complained first about fiscal difficulties - an issue traditionally of paramount importance for the central powers. Their argument was that transfers to new places, initiated two years earlier, had caused a decrease in the income from manufacture and trade in alcohol in the Jewish Suburb (Przedmieście Żydowskie). Another implication was that it was difficult to collect the prescribed local levy ("starosta tax on Jewish lands"), all the more because the majority of those who had moved away were the most affluent residents who, in leaving their dwellings, stripped the owners of houses in the Jewish Suburb of their earnings; some of the buildings thus stood deserted. The Jewish leaders also cited difficulties in ensuring that those living outside the Jewish district purchase kosher meat solely from the community source - a failure that implied decreased proceeds from the levy. To strengthen their position, the petitioners referred to the abundance of places fit for construction within the Jewish Suburb.

32 Ibid., p. 79.

${ }^{33}$ Representatives of the Piotrków synagogue to the Minister of Internal Affairs, 26 Dec. 1811, in AGAD, KRSW, call no. 1439, pp. 34-40. 
Before the representatives of the Jewish kehillah contacted the minister, they requested assistance from the local prefect in Kalisz. As they could expect, he ordered that Jews return to the former Jewish area. After six months, however, no changes had occurred. The community's representatives therefore called on the minister for help, attaching to their plea (paradoxically) an Old Polish decree restricting the area available in Piotrków for Jewish settlement-following the method of Christian burghers. However, the minister declared that "The removal of Jews from the starosta land to the municipal land is not forbidden by any decree of $\mathrm{H}$ [is] R[oyal] H[ighness], and hence the M[inister] of I[nternal] A[ffairs] cannot grant this request." ${ }^{44}$ This meant that Luszczewski would not recognize the former privileges, in opposition to what the prefect did. When the latter endeavored to persuade the minister to change his mind, he conclusively refused, remarking that the Jews "ought not to be denied dwelling" as long as there was no decree designating a Jewish residential area in Piotrków. ${ }^{35} \mathrm{He}$ thereby expressed his view that the former privileges cannot in themselves constitute a foundation for demarcating the zones of residence: instead, a dedicated regulation-namely, a royal decree-would be necessary.

The interior minister took a similar view-this time, along with the local prefect-with respect to the case of a certain Herszek Gimplowicz, tavernkeeper from Sandomierz. In 1811, the latter was forced to leave a starosta's tavern situated in the land excluded from Jewish settlement by a decree of the last Polish king, Stanislaus Augustus. As typically happened also in the old Polish-Lithuanian Commonwealth, the conflict arose not only between the municipality and the Jew, but also between the municipality and the starosta. When Herszek, making use of the new

34 The Minister of Internal Affairs to the representatives of the Piotrków synagogue, 9 Jan. 1812, in ibid., p. 42. Let us note at this point that Dariusz Złotkowski has completely misinterpreted a fragment of this record, stating that Łuszczewski's response was that (under a royal decree) it was severely forbidden for Jews to move from the starosta land to the municipal land; see Dariusz Złotkowski, Miasta departamentu kaliskiego w okresie Księstwa Warszawskiego (Częstochowa, 2001), 261. Cf. also Oskar Flatt, Opis Piotrkowa Trybunalskiego pod względem historycznym i statystycznym (Warsaw, 1850), 56; Moses Feinkind, Dzieje Żydów w Piotrkowie i okolicy od najdawniejszych czasów do chwili obecnej (Piotrków, 1930), 22 (only the prefect's opinion, but not the minister's reply, was known to these two authors).

${ }^{35}$ The Minister of Internal Affairs to the Prefect of the Kalisz Department, 25 May 1812, in AGAD, KRSW, call no. 1439, p. 84. 
official administrative procedures, ${ }^{36}$ appealed to the prefect for help, the latter ordered that the Jewish tavernkeeper be reinstated in the building he leased. As one could expect, the municipality opposed and appealed higher-to the minister, requesting him to keep the royal privileges and decrees issued for Sandomierz. Interestingly, they mentioned the Duchy's Constitution as an argument in favor of their plea-as they claimed this act "does not infringe or destroy" local laws or particular freedoms. ${ }^{37}$ Although, indeed, this act was silent about local laws or privileges, such an interpretation contradicted the spirit of the Constitution. The petitioners, however, were most probably far from competent to be able to understand the new philosophy standing behind this Constitution and referred rather to what they believed this legal act guaranteed.

Łuszczewski was not convinced by the municipality's arguments. Instead, he confirmed the prefect's decision to reinstate the tavernkeeper as "utterly appropriate" and compliant "with the spirit of the law, as well as with the state regulations." ${ }^{38}$ It is worth pointing out that the minister was consistent in his view: when a few months later, referring to another case, a deputy of the town of Sandomierz compiled a petition requesting (among other things) corroboration of the town's privileges, the minister refused, arguing that "the old privileges may not take place at all, with the new Constitution established in this country, being an alteration brought about in the circumstances." ${ }^{39}$

These statements of the ministers expressed the view that the town privileges restricting Jewish residential areas had expired in the Duchy. These privileges were not the only ones. Considering the bestowal of municipal rights on Modlin, the Council of Ministers stated that "according

${ }^{36}$ For more on the usage of administration procedures by the Jewish applicants and on the outcomes of their petitions, see Oniszczuk, "The Jews in the Duchy of Warsaw," 71-81.

37 The Deputy Mayor of Sandomierz to the Minister of Internal Affairs, 26 Aug. 1811, in AGAD, KRSW, call no. 2921, pp. 226-227.

${ }_{38}$ Correspondence between the Deputy Mayor of Sandomierz and the Minister of Internal Affairs, 26 Aug. 1811 and 20 Sept. 1811, in ibid., pp. 221-228. Gimplowicz ranked among the most affluent Sandomierz inhabitants, and thus a positive outcome of his case was all the more probable; in 1811, he won the auction for leasehold of proceeds from the manufacture and sale of liquors (propinacja), based on his offer exceeding by 20 percent the leasehold value in the preceding period. Ibid., pp. 198-200, 219-220.

39 "Description of the condition of the city of Sandomierz," 17 Dec. 1811, in AGAD, KRSW, call no. 2923, pp. 5-6; the Minister of Internal Affairs to the Deputy of Sandomierz, 20 Jan. 1812, in ibid., p. 12. 
to the present form of government, no privileges for establishing towns are necessary, whatsoever." 40

Let us now return to Eisenbach's thesis that the non tolerandis Judaeis privileges were reinstated in the Duchy of Warsaw. How did he base his argument? His incorrect conclusion stemmed from an erroneous premise. Namely, he believed that the legal acts issued in 1807 by the Governing Commission, which was an interim authority, were unquestionably taken over when the Duchy was created. It must be borne in mind, though, that the Commission's decisions were transitory in many cases; their role was to keep order and ensure continuity of the operational administration-particularly involving proceeds from taxes. As members of the Commission hoped that Napoleon would reintroduce the Third of May Constitution, they extensively regulated various domains of life in its vein. However, this did not make legitimate the assumption that such regulations were incorporated, in their entirety, in the Duchy's legal order. The moment the state was formally constituted and adopted the new constitution-whose contents were truly astonishing to members of the Governing Commission-at least some pieces of the interim legislation were no longer valid. This does not mean that an act standardizing this matter was ever issued; due to the enormity of challenges involved in the organization and the need to ensure order, the Commission's legislation was not declared invalid in one single act. Those interim regulations or provisions that were deemed indispensable were retained but they did not determine the policies of the central authorities, the latter being aware of the existence of a completely new legal framework.

Although the ministers themselves did not always know which of the regulations were currently binding, they concordantly agreed that town privileges limiting Jewish places of residence had expired. Nevertheless, they admitted that, for the time being, this change should not be officially announced and that privileges could at times be taken into account. It could happen in cases when they were not in opposition to the "principles of government" (whatever this should have meant) or "good order of things."

There is one more argument against a simple claim that the privilegia de non tolerandis Judaeis were in force in the Duchy. From 1811, attempts

${ }^{40}$ Resolution of the Council of Ministers, 21 Jan. 1812, in AGAD, RM KW, call no. II 186, p. 5. Nevertheless, for the procedure of collecting revenues in private towns, an old privilege was to be perceived as an acceptable legal precedent (Murphy, From Citizens to Subjects, 177-178). 
were made to create Jewish districts in several towns (namely, Wschowa, Płock, Maków Mazowiecki, and Przasnysz); plans existed to extend such regulations to other places (Chorzele, Ciechanów, Lipno, Pułtusk, and Wyszków). ${ }^{41}$ Save for the district in Wschowa, a condition was introduced in the decrees that only "civilized" and most affluent Jews could dwell outside the allotted area. It must be emphasized that these districts were created not because the privileges had been restored: rather, efforts were made to create a formula to replace the privileges. This is attested to by the above-quoted Łuszczewski's statement regarding Lublin and, indirectly, Piotrków. Medieval in its origin, the residential limitation within a town was irreconcilable with the spirit of the Napoleonic law. Therefore, a construction under an altered name (already used by the partitioning states) was coined, and was meant to enable the implementation of partly similar purposes by a new means, referred to as "police regulation." 42 Stated differently, the concept of districts came in lieu of the Old Polish privileges of towns, contemporizing them-that is, adopting them to the new realities in which settlement restrictions were intended to be imposed, for instance, in new places and, certainly, not in the whole town's area. The regulations on districts provided a useful tool also for rewarding those Jews who were considered acculturated and useful to the state's economy. Thus, these regulations were all the better integrated into the modernization projects and declarations (involving care for order, tidiness, and security;

${ }^{41}$ On the districts within these towns, see the Report of the Jewish Committee [Komitet Starozakonnych], 18 July 1826, in AGAD, KRSW, call no. 186, p. 164r, as well as: AGAD, RM KW, call no. II 165, pp. 46-78, 95-105; AGAD, KRSW, call no. 4480, pp. 33-39; AGAD, KRSW, call no. 4586, pp. 104-118, 138-155; AGAD, KRSW, call no. 4709, pp. 50-63; Archiwum Państwowe w Zielonej Górze, collection: Akta miasta Wschowa, call no. 1219, passim; UKW, 2:26-30; UKW, 4:96-100; Eisenbach, "Mobilność," 188; id., Emancypacja Żydów, 154; Esther Schwarz, "Die Juden im Herzogtum Warschau (1807-1813)" (B.A. dissertation, Universität Zürich, Zürich 1975), 52-56; Bartoszewicz, "Projekty rewirów,” 107-111. The plan for setting up a district in Lipno has never been mentioned yet by historiography; a source trace can be found in the document: The Prefect of the Płock Department to the Minister of Internal Affairs, 23 Dec. 1811, in AGAD, KRSW, call no. 4480, p. 35.

${ }^{42}$ The Minister of Internal Affairs to the Council of Ministers, 4 Feb. 1811, in AGAD, RM KW, call no. II 166, p. 29 (Euszczewski pointing to the new character of the "police regulation"); the Minister of Internal Affairs to the Prefect of the Kalisz Department, 25 May 1812, in AGAD, KRSW, call no. 1439, p. 84. Also Artur Eisenbach noticed the novelty in the adopted formula of districts ("a new form of limitations"); he even quotes the interpretation of the Kingdom of Poland's Director of the Treasury who argued in 1854 that the former town privileges and agreements had been revoked in as early as 1802 and in the 1807 Constitution, and that the Jewish districts were arranged in the Duchy and in the Kingdom owing to the police requirements, and not based upon the privileges (Eisenbach, "Mobilność," 185, 247; id., Emancypacja Żydów, 154). 
integration of selected, "civilized" individuals). The authorities of the next state organism, the Kingdom of Poland, merged the two tools - the former privileges and the new districts—-but the observations concerning the policy after 1815 cannot be extrapolated to the Duchy's policy.

As a side remark, worthy of consideration is the minister's firmness when he instructed his subordinates at the departmental and municipal levels about privileges, expressing his position unambiguously. As Curtis Murphy, who analyzed the problem of centralization at the expense of local powers at the turn of the nineteenth century, would presumably have stated, the minister's attitude might have reflected limited trust toward the local authorities, which had already had its roots in the last decades of Poland-Lithuania. At that time it was believed that local authorities had no understanding of the new top-down policy, lacked involvement, or disobeyed the need to implement regulations. In some cases these authorities were even perceived as a hindrance to the improvement of the state governance. ${ }^{43}$ The minister's replies, free of nuances and manifesting the position of power, might have stemmed from the conviction that there was a need to accustom the local powers to absolute obedience and strict following of the headquarters' commands. On the other hand, however, these simple instructions were a better solution than ambiguous interpretations formulated for internal use; pointing to discrepancies between law and political requirements might have been too complicated for the local administration. The prefects needed clear guidelines; otherwise, they would have been helpless and probably would have addressed more queries to the minister, thus distracting the attention of the already overburdened interior department.

\section{Regulations interpreted and implemented at the local level}

The situation at the local level was not easier, however: even though the ministers expressed the view that town privileges were no longer in force, the legal environment was interpreted in a different manner by the local powers. This duality affected the practice. The position initially assumed by the Kalisz prefect with respect to Piotrków has already been mentioned. Also worth noting is the case of the Kraków prefect. In 1811, most probably just in response to a request from a group of burghers of Busko and

${ }^{43}$ Murphy, From Citizens to Subjects, 4-12, 53-57, 80-84, and passim. 
without consulting his ministerial superior, the prefect prescribed that the local Jews move out from the manorial farm situated in the town's limits within three months, arguing that "there is no question about the fact that the Town of Busko holds the privileges forbidding Jews from being housed within the entire town limits, and whose power was retained by the previous [i.e. Austrian; A.O.'s note] government, and not in the least infringed by the present statutes." Among the records, I have come across no letter or notice that would suggest that the matter was ever put on the minister's desk. As it seems, the Jewish population dwelling in the aforesaid manorial farm was not significant; at that time, they were not yet associated in a separate kehillah, and could not count on strong support. Hence, they probably did not decide to send appeal notices to the administration. The subprefect ordered to proceed to expel the Jews (which probably did not lead to the expected or did not have a lasting effect, as the issue was resumed a few years later, under the Kingdom rule). ${ }^{44}$

Worth closer attention is the quoted remark of the Kraków prefect that the old town privileges have been retained in the Duchy and are not in conflict with any new regulations. Such a belief was shared also by some other members of authorities at the local-departmental and municipal-levels (confirmed for the prefect of Kalisz, as well as for the municipalities of Warsaw, Lublin, Kraków, and Sandomierz $)^{45}$ and, certainly, by a considerable portion of the population. Since no announcement was made that town privileges had expired, there was no reason to suppose otherwise. A thought to the contrary might have basically appeared among those thoroughly acquainted with the new Napoleonic law. Yet even if

${ }^{44}$ The Prefect of the Kraków Department to the Subprefect of the Stopnica County (powiat), 30 Sept. 1811, in Archiwum Państwowe w Kielcach [henceforth: APK], collection: Rząd Gubernialny Radomski [henceforth: RGR], call no. 4018, p. 116. In 1818, eviction of Jews was ordered again, based on the Busko privileges; the concordant decision of the Austrian authorities and the prefect's rescript of 1811 were reminded on that occasion. For the complete correspondence on the matter, see ibid., pp. 113-119; also, compare the petition of the inhabitants of Busko to the Subprefect of the Stopnica County, 14 and 19 Apr. 1812, in APK, RGR, call no. 2181, pp. 117-119, 123-124, 127.

${ }^{45}$ Artur Eisenbach, "Status prawny ludności żydowskiej w Warszawie w końcu XVIII i na początku XIX wieku,” Biuletyn Żydowskiego Instytutu Historycznego 39 (1961), 6-11; id., "Mobilność," 187; The Lublin Municipality, together with the burghers, to the Council of State, 24 May 1811, in AGAD, RM KW, call no. II 166, pp. 47-53; Minutes of the meeting of the Kraków Municipal Council, 23 July 1814 and undated (July 1815), in Archiwum Narodowe w Krakowie, collection: Magistrat Krakowa, call no. I/42, pp. 530, 992; Testimony of the Deputy Mayor of Sandomierz, January 1811, in AGAD, KRSW, call no. 2921, p. 118; Deputy Mayor of Sandomierz to the Minister of Internal Affairs, 26 Aug. 1811, in ibid., pp. 221, 227. 
somebody was informed about the interpretation produced by the minister, as was the case with the prefect of Kalisz, this did not readily translate into a change in their view (the prefect insisted on his own understanding in his correspondence to the minister). What this meant is that the privileges continually functioned in the collective awareness, as did the very principle of separation between Christians and Jews. As a practical consequence, municipal authorities in some urban centers presumably proceeded as if the privileges had retained their power, until the specific case was sent to the central authorities for consideration. Once this happened, the latter would make the lower-tier authority aware of its mistake.

Despite the public conviction that the old legal order was still in force, it seems from all indications that, at the minimum, the de non tolerandis Judaeis privileges were not observed in practice, at least in towns previously situated in the Prussian Partition. Esther Schwarz, the author of an interesting thesis on the Duchy, remarks that no confirmation exists, for any town, that such a privilege was reinstated; even if this had been the case, it was to no avail. Her arguments are as follows: within the Duchy's initial territory were seven towns previously holding a non-toleration privilege (Bydgoszcz, Chęciny, Międzyrzec, Opoczno, Sieradz, Warsaw, and Wieluń). According to the statistical findings compiled by Henryk Grossman, a historian and economist, Jews accounted for a smaller or larger proportion of residents in each of these urban centers. Moreover, among the 405 towns in the Duchy, Jews did not reside only in 32-all of these places were small towns in which their settlement had never been forbidden. ${ }^{46}$ The broadening of Jewish presence in cities was noticed just a few years later, after the decline of the Napoleonic state: it was observed at the ministerial level that despite privileges forbidding Jews to settle in certain towns, they "squeezed into" some urban centers "upon consent of the former governments, the Prussian and the Austrian ones, as well as of certain authorities of the Duchy of Warsaw." ${ }^{47}$ It seems plausible that if the non-toleration clause were respected in practice in certain towns,

${ }^{46}$ Henryk Grossman, "Struktura społeczna i gospodarcza Księstwa Warszawskiego na podstawie spisów ludności 1808 i 1810 r.," Kwartalnik Statystyczny 2 (1925), 1:90-106; Schwarz, "Die Juden," 51. Let us note, though, that this author's findings refer to the period before the Austrian Partition area was incorporated-the statistics of towns date from 1808.

${ }^{47}$ Governmental Commission for Internal Affairs to the Voivodeship Commissions, 21 Nov. 1821, in AGAD, KRSW, call no. 185, p. 2r. See also Bruer, Geschichte, 160-161. 
it was rather in formerly Austrian departments-which was much easier due to some continuity: as opposed to Berlin, Vienna did uphold these privileges.

Finally, it is worth recalling how residential restrictions were approached in the capital city, Warsaw. The outcome of the endeavors of Warsaw's municipality was meaningful, as in 1807 it sought confirmation of the old non-toleration privilege- a fact also mentioned by Artur Eisenbach. As he remarked, contrary to the expectations of the city authorities, the existence of a local Jewish community was accepted at the ministerial level. It had the right to elect the elders instead of a syndic who was in office in the period when settlement was forbidden..$^{48}$ Moreover, the central authorities decided in 1809 that the "ticket fee," collected since the late eighteenth century from non-permanent Jewish residents coming to Warsaw, be cancelled. ${ }^{49}$ What epitomized the change in the residential restrictions was also the demography-a wide influx of Jews marked the beginning of a more than century-long Jewish history of the city.

\section{Conclusions}

Law, in principle, is expected to be unambiguous and definitive in its resolutions; until the mid-twentieth century, basically the same was expected in research on the history of law: it was to determine whether a given regulation or provision was in force or not, and which provisions would be relevant to a given case; the focus was on official state law. With the development of the sociology of law as a separate field of research, it has been postulated that the "living" and incessantly changing social reality

48 Eisenbach, "Status prawny," 6-11; id., "Mobilność," 187.

49 The "ticket fee" or "sojourner's tax" (biletowe) was collected in Warsaw since 1770; paid for a fortnight's stay till 1799 , it became a daily fee. The cancellation was decided at the central level in 1809. Dispute around this alteration prolonged in the city for some time, though, and it was finally abolished in 1811 . See The Minister of Justice to the Minister of Internal Affairs, 19 Feb. 1808, in AGAD, KRSW, call no. 6627, p. 13; Hilary Nussbaum, Szkice historyczne z życia Żydów w Warszawie (Warsaw, 1881), 41-42; Ezriel Natan Frenk, "Letoledot ha-Yehudim bi-nesikhut Varsha," Ha-Tekufa 4 (1919), 471-480; Freide Zimmerspitz, "Podatek 'koszerne' i jego dzierżawcy w Księstwie Warszawskim i Królestwie Polskim (1809-1862)" (M.A. dissertation, University of Warsaw, Warsaw, undated), 3, in Archiwum Żydowskiego Instytutu Historycznego, call no. 117/48; Ignacy Schiper, "Samorząd żydowski w Polsce na przełomie wieku 18 i 19-go (1764-1831)," Miesięcznik Żydowski 1 (1931), 1:518; Eisenbach, "Mobilność," 229; Raphael Mahler, Divre yeme Isra'el: Dorot aharonim (Merhavia, 1970), 6:68; Fijałkowski, Warszawska społeczność żydowska, 87-89, 122-125, 132. 
should be taken into account in the research. ${ }^{50}$ As a scholar in the field, Georges Gurvitch, aptly summarized, "the validity of law cannot be established by a simple interpretation and systematization of legislative texts and decisions of tribunals. Legal rules may remain entirely impotent, that is to say, with no application whatsoever, while decisions may contradict each other." Negligence of such a "living," dynamic, and spontaneous law in action, and of "the behavior, practices ..., of the beliefs related to law" implies the danger that the constructed picture would be "entirely disconnected from the law really valid, from the law efficient in a given social milieu." ${ }^{51}$ The privileges issue in the Duchy reflects well the multidimensional character of law, constantly entangled in the social context.

Previous historiography claimed that the Old Polish non tolerandis Judaeis privileges remained in the Duchy of Warsaw in force. What I intended to show, based on an analysis of documents created by central and local authorities, is that for the question on whether these privileges were at that point still valid, a simple "yes" or "no" answer would not mirror the complexity of the Duchy's reality.

To sum up the considerations, town privileges limiting the Jewish residence, including non tolerandis Judaeis ones, were formally no longer in force in the Duchy's legal system. Their restoration by the interim Governing Commission, announced implicitly in January and June 1807, became irrelevant after the state was officially established and adopted a constitutional system completely diverting from the Old Polish model. Although no act was finally passed that would have uniformly regulated the binding power of legacy regulations, town privileges conflicted too strongly with the basic assumptions (or "spirit") of the Napoleonic legislation. This argument was raised, when it came to interpreting the legal system by the ministers who shaped the Jewish policy: the Minister of Justice, the Minister of Internal Affairs, and the Minister of Police. Noteworthy, we may claim that the power of de non tolerandis Judaeis privileges was undermined by the emerging idea of the catalogue of the sources of law, implied in the new legal order. As some of the jurists in the Duchy thought, only the Constitution and royal decrees could regulate the general rights and obligations of the population. ${ }^{52}$ Nevertheless, at the ministerial level

${ }^{50}$ Georges Gurvitch, Sociology of Law (New Brunswick-London, 1973), 4-5.

${ }^{51}$ Ibid., 8-9. See also valuable comments of Marc Galanter, as summarized by Brian Tamanaha, "A Holistic Vision," 90-97.

${ }^{52}$ Interestingly, even though such interpretation was not well established in the ministerial circles, it was not completely alien to well-educated lawyers from the period con- 
obstacles to implementing the new legal rules were considered and it was proposed that the privileges be "taken into account in practice"-at least to the extent that they were in line with the residential policy pursued in respect of Jews in some of the towns.

However, the ministers kept this complicated picture of the legal environment for themselves, refraining from passing it down to their subordinate field offices. As a result, lower-tier interpretations of the legal situation and the local practice were much less nuanced. Prefectures, subprefectures, and municipal offices consisted of clerks seeking unambiguous interpretations of the rules; as the need to pursue daily policy prevailed, they adopted either the option of the privileges' simple validity or invalidity.

Importantly, no legal act was ever issued in the Duchy that would have uniformly regulated the Jewish residence issue across the state. Also, the ministerial guidance was not general: their suggestions were received on an ad hoc basis, whenever a doubt or dispute occurred. Consequently, it was not the legal acts themselves, or in-house ministerial guidance, that shaped the local authorities' beliefs about the binding legal system: it was, basically, ideas about the law in force that had the key role in the pursuance of policies at the local level. Referring to the concept of Leon Petrażycki, the classical sociologist of law, it was a sort of intuitive law, identified with an inner sense of justice. According to the concept of this thinker, apart from the legal text ("positive law"), law consists also of the individual's experience, or idea, of normative facts. A complex interplay incessantly goes on between the two dimensions of law; intuitive law permanently acts as an "invisible, backstage factor," which is sometimes hidden and inappreciable even for those who manage it. ${ }^{53}$

cerned. As a notary from Rawicz commented on limitations in acquisition of real estate by Jews, "There are no other rules for a lawyer than those comprised in the Code, unless there be an altering or novel provision adopted by the superior authority, this being pursuant to the public laws": Wollenhaupt, a Notary, to the Public Prosecutor affiliated to the Civil Tribunal in Poznań, 17 Nov. 1808, in AGAD, KRSW, call no. 6583, p. 4.

${ }^{53}$ In Petrażycki's concept, law is not "something that one may write down and put to the vote but, rather, something that should be 'brought forth in life,' or 'brought to life'." For more on this entanglement of law "in individual and social way of experiencing the reality," see Paweł Jabłoński, Przemysław Kaczmarek, Granice władzy prawniczej w perspektywie polskiej tradycji socjologicznej (Kraków, 2017), 27-29, 68-87, 128. See also Roger Cotterrell, "Leon Petrażycki and Contemporary Socio-Legal Studies," International Journal of Law in Context 11 (2015), 1:1-16. 
Hence, the municipal authorities, subprefects, and prefects adopted decisions or rulings in compliance with their own ideas of what actually constituted binding law. It is moreover certain that the population interpreted the legal status in line with their own priorities, purposes, and habits, making use of mainly traditional notions-particularly, the one of "privilege," which for a long time had been perceived as the foundation, and guarantee, of one's social and economic position (Murphy calls it a "privilege-defending mentality"). The limitation of burghers' privileges, initiated in the late years of the Polish-Lithuanian Commonwealth and manifested in denying them in 1776 the right to sell liquors (the so-called propinacja right), individually and collectively, was firmly resisted at that time, the opponents pointing to the perennial character of the privileges. The new centralizing policy, supported in Warsaw with the argument of a beneficial effect for towns, was not widely accepted. In response, diverse methods were used to limit the effects of the new regulations, the latter interfering considerably in the local status quo. ${ }^{54}$

Thus, we also may argue that despite the departure from the de non tolerandis Judaeis clauses, announced in 1802 under the Prussian Partition in the collective awareness no sudden revision occurred. From the standpoint of the Duchy's Christian burghers, the privileges remained in power and were actually part of a broader picture: privileges continued to form a constituent of group identification. Making use of a general concept of a leading socio-legal theorist, Marc Galanter, we may sum up that the Duchy's official law was limited; it did not "represent the attitudes and concerns of the local people." The issue analyzed proves once again that the "demise of traditional law does not automatically bring the demise

${ }^{54}$ Murphy, From Citizens to Subjects, 7-10, 16-17, 53-120, 159. Interestingly, also in Prussia, even after Stein's and Hardenberg's reforms and despite the trend for abolition of limitations in civil rights, the freedom to choose the abode within urban areas was in practice restricted. This happened from time to time after the emancipation edict of 1812 as well. This is yet another example of a situation where egalitarian regulations were not fully implemented at once, owing to bottom-up resistance. Such incidents appeared in the region of Silesia: despite the guidelines received from the ministry, municipalities still refused individual Jewish applicants the right to dwell in quarters that had been inaccessible to them for decades. See Leszek Ziątkowski, Między niemożliwym a koniecznym. Reformy państwa pruskiego w końcu XVIII i na początku XIX wieku a proces równouprawnienia Żydów ze szczególnym uwzględnieniem sytuacji na Śląsk (Wrocław, 2007), 172-173. For other instances of referring to privileges, see Stefi Wenzel, Jüdische Bürger und kommunale Selbstverwaltung in preußischen Städten 1808-1848 (Berlin, 1967), 169; Michał Szulc, Emanzipation in Stadt und Staat: Die Judenpolitik in Danzig 1807-1847 (Göttingen, 2016), 115-117, 305; Wąsicki, Ziemie polskie pod zaborem pruskim. Prusy Nowowschodnie, 148-149; id., Ziemie polskie pod zaborem pruskim. Prusy Poludniowe, 48-53, 56-63. 
of traditional society" and "various patterns of social ordering, when interacting with official law, are more efficacious ... in influencing social behaviours." 55 The equivocal role of privileges resulted from the Duchy's legal pluralism or multinormativity, meaning various legal and cultural systems, existing side by side..$^{56}$

Finally, it is useful to attempt to compare the validity of town privileges in the Duchy of Warsaw with those in the Kingdom of Poland. Two general conclusions can be stated. First, after the year 1815, the central authorities adopted the assumption that town privileges related to Jews, including the de non tolerandis Judaeis, were continually in force. The innumerable pieces of correspondence, compiled for years at the ministerial level, attest that the assumption was consistently adopted ${ }^{57}$ and opinions voiced to the contrary were unique..$^{58}$ Although the new authorities noticed that many urban centers were populated by Jews under Prussian and Austrian rule, as well as in the Duchy, the postulate to respect the old privileges of the towns was repeated. It seems that the position adopted at the ministerial level was mostly in line, in this particular case, with the views shared by lower-level authorities-particularly in municipalities where the authority circles were not significantly reshuffled after 1815 . What came to an end in the Kingdom was the practice of declaring — rather fictitiously - that the privileges lost their validity, while actions were taken in parallel to prevent any radical change in actual relations (though with use of new instruments-this being the rewiry). In this respect, the central administration of the new state was more forthright. Unbound by the Napoleonic ideals, they abandoned the semblance of political correctness.

55 Tamanaha, "A Holistic Vision," 92-93.

${ }^{56}$ Ibid., 92. On multinormativity see: Aleksandra Oniszczuk, "Public Administration and the Challenge to Introduce Egalitarian Legal Order: The Jewish Policy of the Duchy of Warsaw (1807-1815)," Administory 5 (2020).

${ }^{57}$ For instance, extensive units of AGAD, KRSW, call numbers 185 and 186, abound in such documents (e.g., Correspondence between the Governmental Commission for Internal Affairs and the Commissions of the Voivodeships of Masovia and Kraków, in AGAD, KRSW, call no. 185, pp. 2-18, 230r-232r).

${ }^{58}$ Exceptional was the opinion of one of the governmental commissions (i.e. a sort of ministry under the Kingdom of Poland) -it stated that after the town privileges were abolished by Prussia, no further legal regulation altered the state of affairs (The Governmental Commission for Revenue and Treasury to the Governmental Commission for Internal Affairs, 24 May 1822, in ibid., pp. 20r-21r). Worth recalling is also the quoted above, similar view of the Director of the Treasury (recorded in 1854), mentioned by Eisenbach, "Mobilność," 247. 
Second, it should be remarked that in the Kingdom of Poland the scope of residential restrictions was broader than in its Duchy counterpart: the Kingdom officially sanctioned the existence of privileges apart from, rather than instead of, the districts. And finally, a new ban was imposed; this time on the settlement of Jews within the border area. ${ }^{59}$

Translated by Tristan Korecki

\section{Bibliography}

\section{Archival primary sources and other manuscripts}

Archiv der Universität Zürich

Schwarz Esther, "Die Juden im Herzogtum Warschau (1807-1813)," B.A. dissertation, Universität Zürich, Zürich 1975.

Archiwum Główne Akt Dawnych

Collection: Komisja Rządowa Spraw Wewnętrznych, call numbers: 185, 186, 1439, 2921, 2923, 4480, 4586, 4709, 6583, 6627.

Collection: Rada Ministrów Księstwa Warszawskiego, call numbers: II 165, II 166, II 168, II 186.

Archiwum Narodowe w Krakowie

Collection: Magistrat Krakowa, call no. I/42.

Archiwum Państwowe w Kielcach

Collection: Rząd Gubernialny Radomski, call numbers: 2181, 4018.

Archiwum Państwowe w Zielonej Górze

Collection: Akta miasta Wschowa, call no. 1219.

Archiwum Żydowskiego Instytutu Historycznego w Warszawie, call no. 117/48:

Zimmerspitz Freide, "Podatek 'koszerne' i jego dzierżawcy w Księstwie Warszawskim i Królestwie Polskim (1809-1862)," M.A. dissertation, University of Warsaw, Warsaw, undated (between 1932 and 1939).

\section{Printed primary sources}

Jewish Privileges in the Polish Commonwealth, ed. Jacob Goldberg (Jerusalem, 1985-2001), vols. 1-3.

Materiaty do dziejów Komisji Rządzącej z 1807 r. Dziennik czynności Komisji Rządzącej, ed. Michał Rostworowski (Kraków, 1918), vol. 1.

Ustawodawstwo Księstwa Warszawskiego. Starodawne prawa polskiego pomniki, Series II, Section IV, eds. Wojciech Bartel, Jan Kosim, Władysław Rostocki (Warsaw, 1964-1969).

${ }^{59}$ For the broadest account of the restrictions in the Kingdom of Poland, see ibid., 193-262, 294-316. 


\section{Secondary sources}

Aust Cornelia, "Merchants, Army Suppliers, Bankers: Transnational Connections and the Rise of Warsaw's Jewish Mercantile Elite (1770-1820)," in Glenn Dynner, François Guesnet (eds.), Warsaw. The Jewish Metropolis: Essays in Honor of the 75th Birthday of Professor Antony Polonsky (Leiden-Boston, 2015).

Bałaban Majer, Dzielnica żydowska - jej dzieje i zabytki (Lwów, 1909).

Baranowska Zofia, Baranowski Jerzy, "Dzielnica żydowska i synagoga w Zamościu,” Biuletyn Żydowskiego Instytutu Historycznego 63 (1967).

Bartoszewicz Henryk, "Projekty rewirów dla ludności żydowskiej w miastach mazowieckich 1807-1830," Rocznik Mazowiecki 18 (2006).

Bereza Arkadiusz, "Pozycja monarchy w Księstwie Warszawskim," Studia Iuridica Lublinensia 18 (2012).

Bergman Eleonora, "Ludność żydowska w miasteczkach Mazowsza w XIX i XX w.," in Andrzej Stawarz (ed.), Mazowieckie miasteczka na przestrzeni wieków. Wybrane zagadnienia rozwoju gospodarczego, społecznego i kulturowego (Warsaw, 1999).

Bruer Albert A., Geschichte der Juden in Preußen (1750-1820) (Frankfurt-New York, 1991).

Cotterrell Roger, "Leon Petrażycki and Contemporary Socio-Legal Studies," International Journal of Law in Context 11 (2015), 1.

Czubaty Jarosław, The Duchy of Warsaw, 1807-1815: A Napoleonic Outpost in Central Europe, trans. Ursula Phillips (London, 2016).

Dynner Glenn, "Jewish Quarters: The Economics of Segregation in the Kingdom of Poland," in Rebecca Kobrin, Adam Teller (eds.), Purchasing Power: The Economics of Modern Jewish History (Philadelphia, 2015).

Eisenbach Artur, Emancypacja Żydów na ziemiach polskich 1785-1870 (Warsaw, 1988).

Eisenbach Artur, Kwestia równouprawnienia Żydów w Królestwie Polskim (Warsaw, 1972).

Eisenbach Artur, "Mobilność terytorialna ludności żydowskiej w Królestwie Polskim," in Witold Kula (ed.), Spoteczeństwo Królestwa Polskiego. Studia o uwarstwieniu i ruchliwości społecznej (Warsaw, 1966), 2.

Eisenbach Artur, "Status prawny ludności żydowskiej w Warszawie w końcu XVIII i na początku XIX wieku," Biuletyn Żydowskiego Instytutu Historycznego 39 (1961).

Feinkind Moses, Dzieje Żydów w Piotrkowie i okolicy (Piotrków, 1930).

Fijałkowski Paweł, Warszawska społeczność żydowska w okresie stanisławowskim 1764-1795. Rozwój w dobie wielkich zmian (Warsaw, 2016).

Fijałkowski Paweł, “Żydzi w miastach Mazowsza XIII-XVIII w.," in Andrzej Stawarz (ed.), Mazowieckie miasteczka na przestrzeni wieków. Wybrane zagadnienia rozwoju gospodarczego, społecznego i kulturowego (Warsaw, 1999).

Flatt Oskar, Opis Piotrkowa Trybunalskiego pod względem historycznym i statystycznym (Warsaw, 1850). 
Frenk Ezriel Natan, "Le-toledot ha-Yehudim bi-nesikhut Varsha," Ha-Tekufa 4 (1919).

Gąsiorowski Stefan, “Żydzi w Kiejdanach w XVII i XVIII w. Rekonesans badawczy," in Marcin Wodziński, Anna Michałowska-Mycielska (eds.), Małżeństwo z rozsądku? Żydzi w społeczeństwie dawnej Rzeczypospolitej (Wrocław, 2007).

Goldberg Jacob, "De non tolerandis Iudaeis: On the Introduction of the Anti-Jewish Laws into Polish Towns and the Struggle against Them," in Shmuel Yeivin (ed.), Studies in Jewish History: Presented to Professor Raphael Mahler on His Seventy-Fifth Birthday (Merhavia, 1974).

Grossman Henryk, "Struktura społeczna i gospodarcza Księstwa Warszawskiego na podstawie spisów ludności 1808 i 1810 r.," Kwartalnik Statystyczny 2 (1925), 1.

Grynwaser Hipolit, Kodeks Napoleona w Polsce. Demokracja szlachecka 1795-1831 (Wrocław, 1951).

Guesnet François, Polnische Juden im 19. Jahrhundert: Lebensbedingungen, Rechtsnormen und Organisation im Wandel (Köln-Weimar-Wien, 1998).

Gurvitch Georges, Sociology of Law (New Brunswick-London, 1973).

Heyde Jürgen, “'Ghetto' and the Construction of Jewish History: The Case of the Polish-Lithuanian Commonwealth. Considerations about a Research Project," Kwartalnik Historii Żydów (2004), 4.

Heyde Jürgen, “The 'Ghetto' as a Spatial and Historical Construction - Discourses of Emancipation in France, Germany and Poland," Jahrbuch des Simon-Dubnow-Instituts 4 (2005).

Heyde Jürgen, "Zwischen Polen und Preußen - Die jüdische Bevölkerung in der Zeit der Teilungen Polens," in Helga Schnabel-Schüle, Andreas Gestrich (eds.), Fremde Herrscher - fremdes Volk: Inklusions- und Exklusionsfiguren bei Herrschaftswechseln in Europa (Frankfurt am Main, 2006).

Jabłoński Paweł, Kaczmarek Przemysław, Granice władzy prawniczej w perspektywie polskiej tradycji socjologicznej (Kraków, 2017).

Jehle Manfred, “'Relocations' in South Prussia and New East Prussia: Prussia's Demographic Policy towards the Jews in Occupied Poland 1772-1806," The Leo Baeck Institute Year Book 52 (2007), 1.

Kallas Marian, Organy administracji terytorialnej w Księstwie Warszawskim (Toruń, 1975).

Kaźmierczyk Adam, “Żydzi w miastach prywatnych. Wybrane aspekty,” Roczniki Dziejów Społecznych i Gospodarczych 77 (2016).

Koselleck Reinhart, Preussen zwischen Reform und Revolution: Allgemeines Landrecht, Verwaltung und soziale Bewegung von 1791 bis 1848 (Stuttgart, 1967).

Mahler Raphael, Divre yeme Isra'el: Dorot aharonim (Merhavia, 1970), 6.

Matyjaszek Konrad, Produkcja przestrzeni żydowskiej w dawnej $i$ współczesnej Polsce (Kraków, 2019).

Mazurkiewicz Józef, Jurydyki lubelskie (Wrocław, 1956).

Mazurkiewicz Józef, "Znaczenie akt notarialnych dla badań nad własnością w Księstwie Warszawskim i Królestwie Polskim,” Annales UMCS, Sec. F, 20 (1965).

Michałowska-Mycielska Anna, The Jewish Community: Authority and Social Control in Poznań and Swarzędz 1650-1793 (Warsaw, 2015). 
Michałowska-Mycielska Anna, "Żydzi w strukturze politycznej i administracyjnej Rzeczypospolitej (XVI-XVIII w.)," Przeglad Humanistyczny 58 (2014), 3.

Michalski Jerzy, "Zagadnienie polityki antycechowej w czasach Stanisława Augusta," Przegląd Historyczny 45 (1954), 4.

Murphy Curtis, From Citizens to Subjects: City, State, and the Enlightenment in Poland, Ukraine and Belarus (Pittsburgh, 2018).

Nussbaum Hilary, Szkice historyczne z życia Żydów w Warszawie (Warsaw, 1881).

Oniszczuk Aleksandra, "The Jews in the Duchy of Warsaw: The Question of Equal Rights in Administrative Theory and Practice," Polin 27 (2015).

Oniszczuk Aleksandra, "Public Administration and the Challenge to Introduce Egalitarian Legal Order: The Jewish Policy of the Duchy of Warsaw (18071815)," Administory 5 (2020).

Oniszczuk Aleksandra, Władze Księstwa Warszawskiego wobec Żydów. Debata, prawo, praktyka (Wrocław, 2021) (forthcoming).

Piechotka Maria, Piechotka Kazimierz, "Jewish Districts in the Spatial Structure of Polish Towns," Polin 5 (1990).

Piechotka Maria, Piechotka Kazimierz, Oppidum Judaeorum. Żydzi w przestrzeni miejskiej dawnej Rzeczypospolitej (Warsaw, 2004).

Radwański Zbigniew, Jan Wąsicki, "Wprowadzenie Pruskiego Prawa Krajowego na Ziemiach Polskich," Czasopismo Prawno-Historyczne 6 (1954), 1.

Schiper Ignacy, "Samorząd żydowski w Polsce na przełomie wieku 18 i 19-go (1764-1831)," Miesięcznik Żydowski 1 (1931), 1.

Sobociński Władysław, Historia ustroju i prawa Księstwa Warszawskiego (Toruń, 1964).

Stanley John, "The Politics of the Jewish Question in the Duchy of Warsaw, 1807-1813," Jewish Social Studies 44 (1982), 1.

Szczepański Janusz, Dzieje społeczności żydowskiej powiatów Pultusk i Maków Mazowiecki (Warsaw, 1993).

Szczepański Janusz, Społeczność żydowska Mazowsza w XIX-XX wieku (Pułtusk, 2005).

Szulc Michał, Emanzipation in Stadt und Staat: Die Judenpolitik in Danzig 1807-1847 (Göttingen, 2016).

Tamanaha Brian, "A Holistic Vision of the Socio-Legal Terrain," Law and Contemporary Problems 71 (2008), 2.

Wąsicki Jan, Ziemie polskie pod zaborem pruskim. Prusy Nowowschodnie (Neuostpreussen) 1795-1806 (Poznań, 1963).

Wąsicki Jan, Ziemie polskie pod zaborem pruskim. Prusy Południowe 1793-1806. Studium historycznoprawne (Wrocław, 1957).

Węgrzynek Hanna, "Illegal Immigrants: The Jews of Warsaw, 1527-1792," in Glenn Dynner, François Guesnet (eds.), Warsaw. The Jewish Metropolis: Essays in Honor of the 75th Birthday of Professor Antony Polonsky (Leiden-Boston, 2015). Wenzel Stefi, Jüdische Bürger und kommunale Selbstverwaltung in preußischen Städten 1808-1848 (Berlin, 1967). 
Willaume Juliusz, Fryderyk August jako książe warszawski (1807-1815) (Poznań, 1939).

Wojtkowski Andrzej, Polityka rzadu pruskiego wobec Żydów polskich od roku 1793 do 1806 (Poznań, 1923).

Ziątkowski Leszek, Między niemożliwym a koniecznym. Reformy państwa pruskiego w końcu XVIII i na początku XIX wieku a proces równouprawnienia Żydów ze szczególnym uwzględnieniem sytuacji na Śląsku (Wrocław, 2007).

Złotkowski Dariusz, Miasta departamentu kaliskiego w okresie Księstwa Warszawskiego (Częstochowa, 2001).

Aleksandra Oniszczuk

University of Warsaw ae.oniszczuk@uw.edu.pl 